Ophthal. Res. 1974;6:65-70

\title{
Contents, Vol. 6, No. 2, 1974
}

\section{Contents}

Nordmann, J. (Strasbourg): Preface (VII) 71

Bagchi, M. and Harding, C.V. (Detroit, Mich.): Characterization of Specific Subphases prior to DNA Synthesis in Mammalian Lens Epithelium (1) 73 Bloemendal, H. and Herbrink, P. (Nijmegen): Growing Insight into the Structure of /3-crystallin. A Review (9) 81

Chylack, L.T., jr. (Boston, Mass.): Soluble, Insoluble and Latent Hexokinases in the Mammalian Lens (21) 93

Cotlier, E.; Sanders, D., and Wyhinny, G. (Chicago, 111.): Effects of Cetylpyridinium Chloride on the Membranes of the Lens Fibers and on Lens Permeability, Hydration and 22Na and 86Rb Transport $\quad$ (35) 107 Friedburg, D.; Kroner, H., and Rosenstiel, L. (Düsseldorf): In vivo Action of Corticosteroids on the Guinea Pig Lens (59) 131 Iwata, S. (Osaka): Process of Lens Opacification and Membrane Function: A Review (66) 138

Kabasawa, L; Lou, M.F.; Merola, L.O., and Kinoshita, J.H. (Boston, Mass.): Inositol-1-Phosphatase in the Lens (83) 155

Kern, H.L. and Ho, C.-K. (New York, N.Y.): Transport of Dicarboxylic Amino Acids in the Rat Lens (94) 166

Koch, H.R.; Kremer, F.; Linner, E.; Hockwin, O.; Kaufmann, H.; Breull,W. , and Dahners, H.W. (Bonn, Umeå): On the Influence of a Monolateral Carotid Ligation Upon the Formation of Radiation Cataracts in Rats. (With Colour Plate I) (103) 175 Korte, Inge; Werry, W.D., and Hockwin, O. (Bonn): Separation and Deter mination of Free Nucleotides in Calf and Mature Bovine Lenses by ThinLayer Chromatography (111) 183 Kuck, J.F.R., jr. and Crosswell, H.H., jr. (Atlanta, Ga.): Lens as the Chief Source of Fructose in Rabbit Aqueous Humor $\quad$ (117) 189 Maraini, G. and Torcoli, D. (Parma): Electrolyte Changes in the Lens in Senile Cataract (125) 197

Mizuno, G.; Ellison, E.; Chipault, J.R., and Harris, J.E. (Minneapolis, Minn.): Lipids of the Triparanol Cataract in the Rat (134) 206

\section{Contents (VI)}

Nordmann, J.; Mack, G., and Mack, G. (Strasbourg): Nucleus of the Human Lens. III. Its Separation, its Hardness (144) 216

Ohrloff, C.; Hockwin, O., and Licht, W. (Bonn): Ketohexokinase Activity in Whole Bovine Lenses and Single Lens Parts in Dependence on Age ... (151) 223 Reim, M.; Heuvels, B., and Cattepoel, H. (Marburg): Glutathione Peroxidase in Some Ocular Tissues 
Swanson, A. A. and Truesdale, A.W. (Charleston, S.C.): Isolation and Puri fication of Arylamidase from Human Lenses (163) 235

York, A. T. and Manski, W. (New York, N.Y.): Quantitative Polyacrylamide Gel Electrophoresis of Crystallin and Solubilized Albuminoid Lens Pro teins (173) 245

Zigman, S.; Yulo, T., and Schultz, J. (Rochester, N.Y.): Cataract Induction in Mice Exposed to Near UV Light (187) 259 